\title{
Seasonal Succession of the Plankton and Microbenthos in a Hypertrophic Shallow Water Reservoir at Modra (W Slovakia)
}

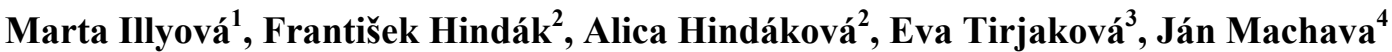 \\ ${ }^{1}$ Institute of Zoology, Slovak Academy of Sciences, Dúbravská Cesta 9, Bratislava, Slovakia; ${ }^{2}$ Institute of Botany, Slovak Academy \\ of Sciences, Dúbravská Cesta 9, Bratislava, Slovakia; ${ }^{3}$ Department of Zoology, Faculty of Natural Sciences, Comenius University, \\ Bratislava, Slovakia; ${ }^{4}$ Catholic University in Ružomberok, PF, Hrabovská Cesta 1, Ružomberok, Slovakia. \\ Email: marta.illyova@savba.sk
}

Received September $2^{\text {nd }}, 2013$; revised October $1^{\text {st }}, 2013$; accepted October $26^{\text {th }}, 2013$

Copyright (C) 2013 Marta Illyová et al. This is an open access article distributed under the Creative Commons Attribution License, which permits unrestricted use, distribution, and reproduction in any medium, provided the original work is properly cited.

\begin{abstract}
The seasonal development of the phytoplankton, phytobenthos, zooplankton, and microbenthos in a high eutrophised intravilan water reservoir was studied. Finally, 25 genera with 44 species of Cyanobacteria/Cyanophytes and 67 genera with 102 species as well as infraspecific taxa of different groups of microscopic algae were identified. The phytoplankton in most parts of the water basin was strongly dominated by green colonial alga Golenkiniopsis longispina. From October until December a cyanophyte species Aphanocapsa delicatissima with typical cell dimensions of picoplankton/ was found in large amounts/predominated. As early as spring, a plankton bloom in all its components was observed. At that time, also a high concentration of total phosphorus was recorded, which in the second half of April dropped rapidly. The concentration of chlorophyll- $a$ increased from $162.7 \mu \mathrm{g} / \mathrm{L}$ in March to $2322 \mu \mathrm{g} / \mathrm{L}$ in September. Massive occurrence of benthic protozoa in the plankton, as a consequence of anoxia, has been observed. Further, the detritivore and omnivore ciliate species Coleps hirtus dominated in the microbenthos. Altogether 74 of ciliate taxa were detected. Their abundance and biomass reached peak in April, but these steadily decreased from May until the end of the year. Extreme values of zooplankton density $(54,016 \mathrm{ind} / \mathrm{L})$ were recorded in spring followed by a sudden fall in summer and autumn. The contribution of rotifers (Brachionus spp., Filinia longiseta) in the total zooplankton density and biomass was $98 \%$. Relatively a low species richness of crustaceans (4 Cladocera and 3 Copepoda) was observed.
\end{abstract}

Keywords: Cyanobacterial Water Blooms; Eutrophication; Ciliates; Zooplankton; Shallow Ponds

\section{Introduction}

Cultural eutrophication is the Earth's most widespread water quality problem. It causes harmful algal blooms, fish kills and many related problems in fresh waters that are adjacent to areas with large human populations [1].

The small size and shallow water bodies are less stable than larger lakes, and thus very sensitive to any human intervention. Pollution from agriculture and sewage is recognized as having a significant negative impact on water quality and aquatic biota [2], besides the fish stock [3]. The biological reaction of aquatic system to nutrient enrichment is the eutrophication, the eventual conesquence of which is the development of primary production to nuisance proportions [4]. Free dissolved phospho- rus and nitrogen are important nutrients for photosynthetic organisms [5], mainly for cyanobacterial blooms [6, 7]. Eutrophication causes considerable changes in biochemical cycles and biological communities [8]. Community interaction in pelagic food webs is affected by large scale of physical, chemical and biological processes and are govern by nutrient limitation, competition, predation and other ecological forces $[9,10]$. In shallow waters, trophic level interactions are complicated by detritus pathways and influences from the sediments [11].

In this paper we describe the seasonal development of phytoplankton, algal picoplankton, cyanobacterial bloom, ciliates and metazooplankton in small hypertrophic urban reservoir in 2009 and try to elucidate some interactions between food web components. 


\section{Material and Methods}

The water basin which is situated within the area of Modra (town in W Slovakia, 48 $18^{\prime} 55.28^{\prime \prime} \mathrm{N}, 17^{\circ} 19^{\prime} 2.4^{\prime \prime} \mathrm{E}$ ) was originally built and created as a flood control reservoir for the town. The access path and the drive-way for the fire truck machinery to the basin as well as the concrete edges along the whole circumference of its area are clear evidence of this reality "Figure 1". However, for the past decades, it has served as a fishpond. The water basin lies at an altitude of 144 meters and its surface covers 0.55 hectares. The maximum depth of this reservoir, at high level water conditions, is 2 meters and it has neither regular direct inflow nor outflow. Due to this fact, the only way how the water basin obtains water is from snow-melt during winter and spring seasons and from rainfall throughout the year. Furthermore, a certain amount of nutrition gets into the basin from local people by feeding the fish.

Our research was carried out from February to December 2009. During this investigation period samples were taken at monthly intervals. The physical and chemical water parameters are as follows: water temperature $\left({ }^{\circ} \mathrm{C}\right), \mathrm{pH}$, oxygen content $(\mathrm{mg} \cdot \mathrm{L})$ and oxygen saturation $(\%)$. All the parameters were measured near the surface in situ by a multi-functional instrument WTW 80 1i according to relevant working methods and processes. The content of dissolved phosphorus (TRP) $(\mu \mathrm{g} / \mathrm{L})$ was evaluated according to standard analytical techniques (STN EN ISO 6878); total phosphorus (TP) and total nitrogen (TN) were determined by a spectrophotometer DR 2800; and the chlorophyll-a concentration was evaluated by means of the standard method (ISO 10260:1992). Phytoplankton samples were taken by plankton net in mesh size of $10 \mu \mathrm{m}$. Cyanobacteria and algae were determined merely from fresh samples, diatoms were defined from permanent slides as well. For the determination of phototrophic microorganisms several monographs were used [12-17].

Ciliophora were studied in plankton and benthos. Plankton samples were collected from a single spot in the studied basin, using a take-off apparatus placed on a 3meter long telescopic pole, while benthic samples were taken from four sampling sites. The analysis of samples was conducted in vivo by means of a light microscope within 8 hours after sample collection. Taxonomically difficult species were examined also in protargol-impregnated slides whose preparation followed the protocol as described by Foissner [18]. Quantitative evaluation of ciliate abundances included enumerating of active ciliates in 10 subsamples, each with a volume of $10 \mu \mathrm{L}$. The obtained data were consequently recalculated to $1 \mathrm{~mL}$. The estimation of the total biomass was based on the mean biomass values for particular species as given in

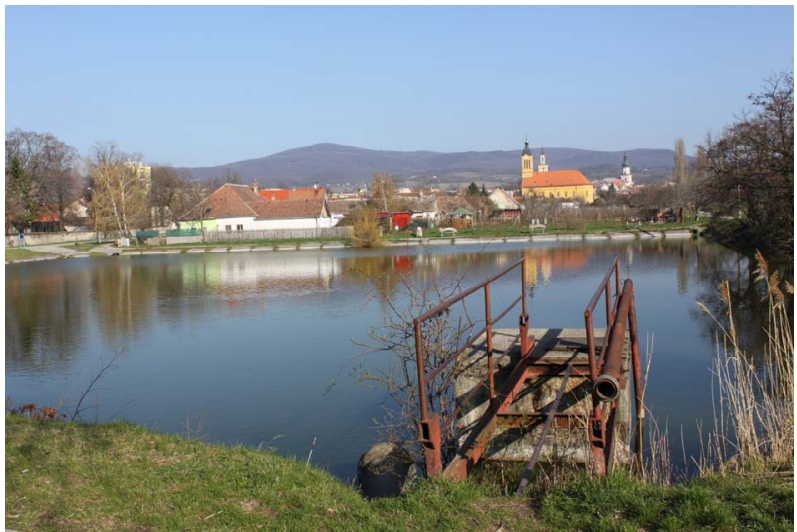

Figure 1. Water reservoir in Modra; right bottom (Photo F. Hindák).

the determination atlases of Foissner et al. [18-22].

The metazooplankton samples for the qualitative analysis were taken by vertical tows from the bottom by a plankton net (70 $\mu \mathrm{m}$ mesh size). The qualitative samples were taken with a 2 L Patalas sampler from various depths of the basin (surface, middle and bottom). The entire water volume $(10 \mathrm{~L})$ was filtered through a net of $70 \mu \mathrm{m}$ mesh size and preserved with $4 \%$ formalin. The zooplankton density (ind/L) was assessed in a $1 \mathrm{~mL}$ Sedgwick-Rafter chamber. The biomass $\left(\mathrm{g} / \mathrm{m}^{3}\right)$ was established as wet weight and it was calculated from the recorded average body lengths and the body length/biomass ratio using tables assembled from several bibliographic sources [23-27].

\section{Results}

\subsection{Physical and Chemical Variables}

In the season of 2009 , high annual mean values of nitrogen, phosphorus and chlorophyll-a were recorded "Table 1". It is notable that during the first months of our investigation, from end of March until May, low values of oxygen were recorded due to respiration having been in process during the night before "Figure 2". For instance, in March 27 the value for oxygen was $6.07 \mathrm{mg} / \mathrm{L}$ and in April 03 we even witnessed oxygen of $4.25 \mathrm{mg} / \mathrm{L}$. Over the entire period of our research, high $\mathrm{pH}$ values were measured in the water basin peaking in April with $\mathrm{pH}$ 10.81 and in May with $\mathrm{pH}$ 10.42. The concentration of total reactive phosphorus (TRP) in the water reached $42.7 \mu \mathrm{g} / \mathrm{L}$ after the ice melted (February 25). The maximum value of TRP was recorded in early March "Figure 3". Although the highest inflow concentration of TRP, $1240.8 \mu \mathrm{g} / \mathrm{L}$ was supposed on April 08, it occurred earlier, in April 03 with a high value of TRP concentration $652 \mu \mathrm{g} / \mathrm{L}$. Meanwhile, in the course of April this value was gradually decreasing and at the end of the month (April 29) it reached $180 \mu \mathrm{g} / \mathrm{L}$. In the second half of the 
Table 1. Annual average values and ranges for selected variables in 2009.

\begin{tabular}{|c|c|c|c|}
\hline Variable (unit) & Mean & Minimum & Maximum \\
\hline Water temperature $\left({ }^{\circ} \mathrm{C}\right)$ & 16.6 & 1.3 & 26 \\
\hline $\mathrm{pH}$ value & 9.34 & 8.06 & 10.81 \\
\hline Oxygen (mg/L) & 12.88 & 4.24 & 25.97 \\
\hline Oxygen (\%) & 131 & 7.5 & 315 \\
\hline $\mathrm{SRP}(\mu \mathrm{g} / \mathrm{L})$ & 310.77 & 14.38 & 1244.80 \\
\hline Total phosphorus $(\mu \mathrm{g} / \mathrm{L})$ & 614 & 75 & 1550 \\
\hline Total nitrogen $(\mathrm{mg} / \mathrm{L})$ & 9.51 & 0.56 & 22.85 \\
\hline $\mathrm{BOD}_{5}(\mathrm{mg} / \mathrm{L})$ & 7.49 & 5.15 & 9.67 \\
\hline CHSK (mg/L) & 147.8 & 23.7 & 534.3 \\
\hline $\mathrm{SO}_{4}(\mathrm{mg} / \mathrm{L})$ & 93.5 & 60.4 & 141.7 \\
\hline $\mathrm{NO}_{3}(\mathrm{mg} / \mathrm{L})$ & 5.8 & 0.32 & 16.2 \\
\hline $\mathrm{Cl}(\mathrm{mg} / \mathrm{L})$ & 45.14 & 0.62 & 227 \\
\hline $\mathrm{Na}(\mathrm{mg} / \mathrm{L})$ & 21.2 & 18.3 & 25.4 \\
\hline $\mathrm{K}(\mathrm{mg} / \mathrm{L})$ & 31.5 & 22.9 & 37.1 \\
\hline $\mathrm{Mg}(\mathrm{mg} / \mathrm{L})$ & 20.8 & 14.5 & 31.1 \\
\hline $\mathrm{Ca}(\mathrm{mg} / \mathrm{L})$ & 31.4 & 10.1 & 82 \\
\hline Chlorophyll-a $(\mu \mathrm{g} / \mathrm{L})$ & 947.3 & 208.3 & 2322.4 \\
\hline Conductivity $(\mathrm{mS} / \mathrm{cm})$ & 553 & 460 & 802 \\
\hline
\end{tabular}

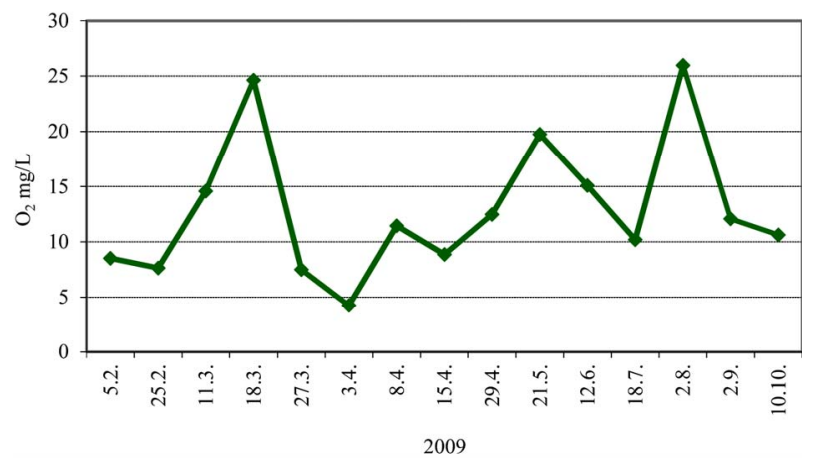

Figure 2. Seasonal development of oxygen $(\mathrm{mg} / \mathrm{L})$ in 2009.

vegetation season, from August and November, the TRP values tended to be low "Figure 3". During the season the concentration of chlorophyll-a was increasing strongly ranging from the lowest values in March 162.7 $\mu \mathrm{g} / \mathrm{L}$ up to maximum values in September $2322 \mu \mathrm{g} / \mathrm{L}$; high values over $1000 \mu \mathrm{g} / \mathrm{L}$ also persisted in October as well as in November.

\subsection{Phytoplankton}

Centric diatoms Stephanodiscus hantschii and Cyc-

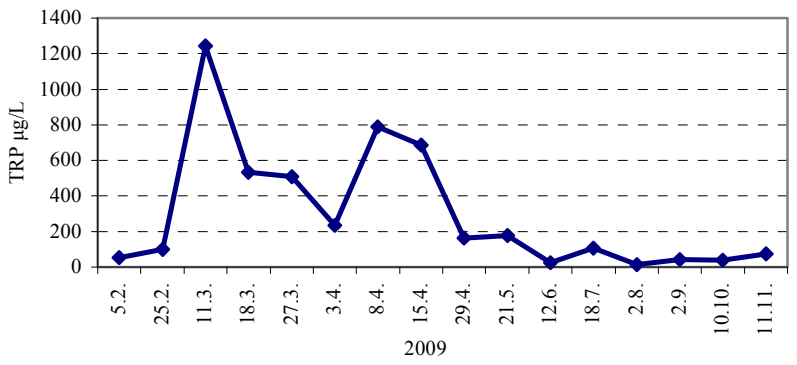

Figure 3. Seasonal development of soluble reactive phosphorus (TRP) $(\mu \mathrm{g} / \mathrm{L})$ in 2009.

lostephanos invisitatus together with cyanobacteria $\mathrm{Mi}$ crocystis ichtyoblabe and Aphanizomenon gracile dominated the phytoplankton from early spring (March-April) and this fact had a major effect on the colour of the water which appeared to be brown greenish. At the end of April and in May the mass development of the green colonial alga Golenkiniopsis longispina was manifested and the colour of water changed into green or dark green. Sporadically and usually in small numbers also some other chloroccalean algae were observed from the genera Scenedesmus, Oocystella, Monoraphidium, and species Coenococcus planctonicus, Dictyosphaerium tetrachotomum, Kirchneriella obesa, Lagerheimia longiseta, $L$. wratislaviensis, Micractinium pusillum, Pediastrum boryanum, Pseudodictyosphaerium minutum, Scenedesmus pectinatus, Siderocelis ornata, Siderocystopsis fusca and Tetraedron caudatum [28].

It was interesting to see and it should certainly be pointed out that some groups of algae, e.g. diatoms, desmids or algal flagellates were almost missing in summer and autumn. Only occasionally a green neustonic film, caused by Chlamydomonas debaryana, was formed at the edge of the reservoir or Euglena viridis was concentrated at the bottom of the reservoir. Periphyton was composed of filamentous microorganisms from cyanobacteria Homoeothrix janthina, Oscillatoria janus, $O$. princeps, Phormidium tenue, Calothrix fusca, from green algae Oedogonium sp., Aphanochaete repens and zygnematophycean algae from the genera Mougeotia, Spirogyra and Zygnema. The cyanobacterial water bloom started to be obvious and evident from May. At the beginning it was dominated by the colonies of Microcystis ichtyoblabe, later on (from July to early August) by a rare nostocalean species, Cylindrospermopsis raciborskii. Terminal heterocytes were formed very rarely; thus the majority of filaments resembled similar species-Raphidiopsis mediterranea. From August until the end of the season in December colonies of chroococcal cyanobacterium Aphanocapsa delicatissima with cells of picoplanktic size (1-2 $2 \mu \mathrm{m}$ in diameter) dominated very strongly. Taxa Microcystis botrys, M. aeruginosa and Anabaenopsis milleri ranked among the group of accompanying 
species of cyanobacterial water blooms.

\subsection{Ciliates and Microbenthos}

Totaly 74 taxa of ciliates were identified during the year 2009 [29]. The highest species richness of ciliates was recorded in March (12). On the other hand, the lowest number of species (5 - 8 species) was observed during the second half of the year. The seasonal changes in biomass and abundance of ciliates are shown in "Figure 4". Cell abundance ranged from 305 to $10,570 \mathrm{ind} / \mathrm{mL}$. The mean ciliate number was $2595 \mathrm{ind} / \mathrm{mL}$. Biomass ranged from 2870 to $296,690 \mathrm{mg} / \mathrm{mL}$, averaging 71,491 $\mathrm{mg} / \mathrm{mL}$. At the beginning of the vegetation season, i.e. in March, the community structure was stabilized with an average density of $300-400 \mathrm{ind} / \mathrm{mL}$ and a moderate domination of members of the genus Vorticella. In April, a boom of ciliate growth was noticed (over 10,000 ind $/ \mathrm{mL}$ ), which was primarily the result of a mass occurrence of the prostomatid Coleps hirtus. Also Pseudovorticella natans was recorded during early spring at a relatively high abundance (400 ind $/ \mathrm{mL}$ ). Moreover, a few large ciliate species, such as Linostomella vorticella and Paramecium caudatum were observed. In May, the ciliate density in the plankton dropped approximately to $2500 \mathrm{ind} / \mathrm{mL}$. Coleps hirtus fell back, but the bacterivorous Cinetochilum margaritaceum, which feeds also on small aglae, became dominant. Some benthic species, Spirostomum teres and Holophrya teres, were noted in the plankton. This is a consequence of anoxia in the benthos, and this phenomenon became very conspicuous in June when the ciliate density in the plankton $(\approx 6000$ $\mathrm{ind} / \mathrm{mL}$ ) was several times higher than that in the benthos (1000 ind $/ \mathrm{mL}$ ). During this period there was a comparatively poor species spectrum (5 - 8 species) with Coleps hirtus and Cinetochilum margaritaceum being dominant both in the plankton and in the benthos. In the July plankton, there was an overall decrease of ciliate densities $(\approx 1200 \mathrm{ind} / \mathrm{mL})$, but the number of species increased moderately to 12 . The community was equable and no species was dominanting over other ones. Small bacterivorous species, such as Ctedoctema acanthocryptum, Cyclidium glaucoma and Cinetochilum margaritaceum are characteristic for this period.

Species of algal and cyanobacterial diet, especially, Frontonia leucas and Halteria grandinella began to occur in the summer communities. Further, algivorous and bacteriovorous species (Pseudocohnilembus pusillus, Cinetochilum margaritaceum) replaced the predatory species in benthos. Frontonia leucas was the most dominant algivorous species in the summer months, but disappeared in September when the bacteriovorous species Dexiotricha tranquilla became dominant both in the plankton and in the benthos. As concerns predatory

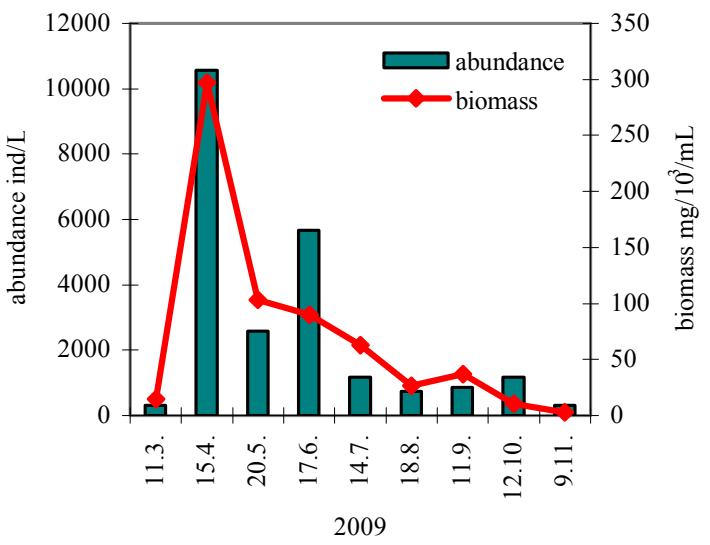

Figure 4. Seasonal development of abundance (ind $/ \mathrm{mL}$ ) and total biomass $\left(\mathrm{mg} \cdot 10^{-3} \mathrm{~m} / \mathrm{L}\right)$ of ciliates in 2009 .

gymnostomate ciliates, members of the genus Actinobolina occurred mainly in spring and summer. At the same time, a high abundance of colonial peritrichous ciliates of the genus Epistylis (E. chrysemydis and E. enzii) was recorded mostly in the benthos. By contrast, typical planktobionts such as Rimostrombidium, Limnostrombidium, Tintinidium and Hastatella were noted only rarely and at low abundance.

\subsection{Metazooplankton and Rotifers}

The season of changes in biomass and abundance of zooplankton are showen in "Figure 5", the changes in biomass of rotifers, cladocerans and copepods in "Figure 6". The abundance of the zooplankton ranged during the sampling period from $102 \mathrm{ind} / \mathrm{L}$ up to 54,016 ind/L. The metazooplankton was dominated by rotifers, which contributed $98 \%$ of its total density and $91.6 \%$ of the total zooplankton biomass. Accordingly, it can be stated that the seasonal dynamics of the abundance of total net zooplankton copies the seasonal dynamics of the abundance of rotifers. As early as March, a very unusual abundance of rotifers was recorded $(15,680 \mathrm{ind} / \mathrm{L})$. Moreover, this high density production kept increasing and in April reached extremely high values $(53,712$ ind/L) with the dominance of the genus Polyarthra (92\%). Although in April the biomass of rotifers was high, it reached its maximum level in July. We started to witness a species dominance of Brachionus budapestinesis (57\%) and Filinia longiseta $(36 \%)$. In the second half of the vegetation season a considerable drop of rotifers was observed "Figure 5". While at the beginning of autumn the dominance of $B$. budapestinensis ( $85 \%$ ) was still prevailing, in November only two species (Keratella quadrata and Cephalodella gibba) of a very low abundance were found.

The proportion of cladocerans to total quantity was considered low and their ratio to the total biomass indi- 


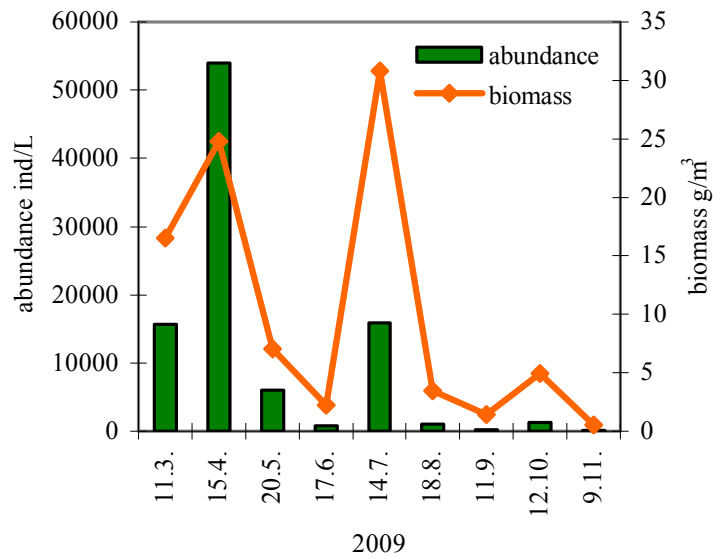

Figure 5. Seasonal development of abundance (ind/L) and total biomass $(\mathrm{g} / \mathrm{m})$ of net zooplankton in 2009.

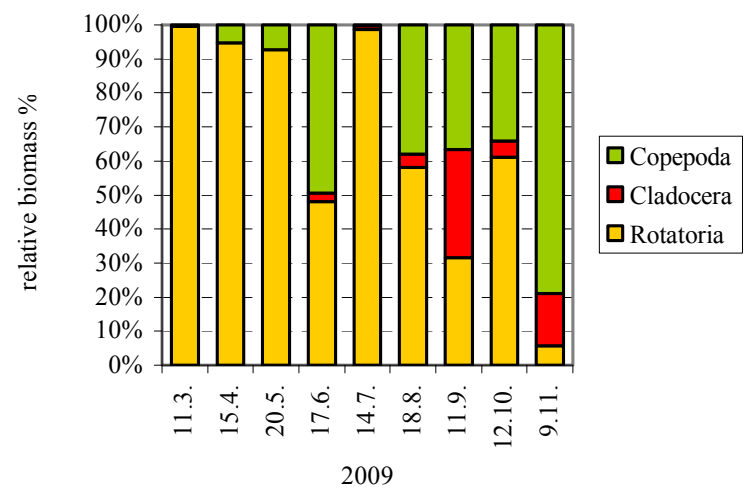

Figure 6. Seasonality of biomass (\%) proportions of all groups of net zooplankton in 2009.

cated $1.4 \%$; however, during the autumn months their relative biomass increased due to a regress of rotifers "Figure 6". The most important cladoceran species was Alona rectangula with abundance ratio from $2 \mathrm{ind} / \mathrm{L}$ to $44 \mathrm{ind} / \mathrm{L}$. In addition to Alona, also a rare occurrence of Chydorus sphaericus was observed. The contribution of copepods in a total zooplankton biomass came to $7 \%$. Throughout the whole season the copepods were present mostly as nauplii and small copepodites, adult being rare (Acanthocyclops trajani).

\section{Discussion}

There are some evidence about the high eutrophication of water body in the reservoir: 1) cyanobacterial bloom and high chlorophyll-a content as a consequence of a high phosphorus content; 2) changes in species composition of planktonic communities, decrease of quantity and species biodiversity at all plankton communities and microbenthos; 3) anoxia at the bottom of reservoir indicated by protozoan community.

1) The bloom of filamentous cyanobacteria in the half of the summer is an indication of the eutrophic to the hypertrophic state of the Modra reservoir. For example, Cylindrospermopsis raciborskii which is adapted to low light conditions is able to fix atmospheric nitrogen [30]. The small reservoir at Modra can be described as a typical pond with massive technical modification and with no original macrovegetation [31]. It can be assumed that its water is rich in nutrients and tied to sediments what is very typical for all small water basins and fishponds [3], or urban lakes [32]. The high concentration of chlorophyll-a and the dominance of cyanobacteria as well as of green algae (namely Chlorococcales) over the vegetation period indicated a high trophic level in the water basin and the high rate of primary production. It is generally agreed that if there is a sufficient source of nutrients in water, phosphorus particularly, an excessive phytoplankton production occurs cf. [33]. Phosphorus is often found to be the limiting nutrient in inland fresh waters $[10,34]$. Values in excess of $30 \mu \mathrm{g} / \mathrm{L}$ ortho-phosphate phosphorus $\left(\mathrm{PO}_{4}-\mathrm{P}\right)$ in river waters and in excess of $20 \mu \mathrm{g} / \mathrm{L}$ total $\mathrm{P}$ (Ptot) in lakes are considered by the Irish EPA to lead to eutrophication [35].

However, as far as spring we measured and recorded far higher values for the reactive as well as total phosphorus concentration which largely determined the excessive production of phytoplankton. This corresponds well with the findings published by [36] that found out a linear correlation between TP and the maximum phytoplankton biomass at the beginning of vegetation season. In spring, in addition to diatoms, a proliferation of cyanobacteria from the genus Microcyctis was observed at Modra. For the period of winter the green colour of water showed itself through the ice which is not an unusual phenomenon. The production of cyanophytes below the ice at the temperature of $3^{\circ} \mathrm{C}$ was also observed by Maršálek [37], or by Kiss and Genkal [38]. The high values of phosphorus remained until the middle of April which was followed by a sudden drop presumably due to consumed phosphorus at the massive phytoplankton development. This manifested itself also with high values of alkaloids, as they increase the values of $\mathrm{pH}$ in their surroundings even to $9-11$ by their metabolic activities [37].

2) During the period of our investigation 25 genera with 44 species of cyanophytes and 67 genera with 102 species as well as infraspecific taxa of different groups of microscopic algae were identified [28]. Five are the first records from the territory in the Slovak Republic cf. [39], i.e. two species of cyanobacteria: Synechococcus mucicola Joosten, Synechocystis endophytica (G. M. Smith) Joosten, and three species of green algae: Nautococcus mamillatus Korshikov, Bicuspidella incus Pascher, Desmatractum indutum Pascher [28]. However, the phytoplankton diversity was generally lower in comparison 
with other eutrophic waters in Western Slovakia cf. [40].

Eutrophication causes considerable changes in biochemical cycles and biological communities [8]. In the Modra reservoir, the response of planktonic and benthic ciliates on the phytoplankton development was manifested as a change in the ciliate community structure [29]. The omnivorous species were replaced by algivorous and bacterivorous ones. Ciliates seem to be very flexible in reaction to environmental changes since many of them are capable to alter their food sources upon the offer within a relatively short time. Dias and D' Agosto [41] found out that Frontonia leucas feeds especially on diatoms in oligotrophic waters and only rarely consumes bacteria and cyanobacteria. However, the diet of this species changes when saprobiological level increases. In Modra, abundance of $F$. leucas raised in summer after a massive development of cyanobacteria and green algae especially Golenkiniopsis. Due to the high feeding activity, this ciliate species could play a key role in reduction of water bloom [42]. These authors also showed that Halteria grandinella is another good candidate for reduction of water bloom, as it consumed over $70 \%$ of all cyanobacteria which were engulfed by ciliates. These findings are supported also by our observations in that $H$. grandinella and also $F$. leucas co-occurred in the period with a maximum developed cyanobacterial water-bloom. Also Vörösváry [43] recorded an increased occurrence of algivorous and bacterivorous species, especially from the genera Chilodonella, Colpidium, Stylonychia, Coleps, Paramecium and Frontonia as well as of species living on organic remnants (Spirostomum) in a stream with water bloom due to the pollution by sewage waters. Thus, these taxa can be potentially used in suppression of water bloom. Peritrichous filter feeders, which often occur at high abundances in benthos, could be also highly effective in elimination of water bloom [44].

The hypertrophic conditions of the water body in Modra were documented also by the net zooplankton community: the extremely high abundance of the rotifers in spring and extremely low planktonic crustaceans. The extreme abundance of rotifera at the beginning of the vegetation season draw the parallel between them and the maximum values in spring which is the typical standard for pond ecosystems [3]. The maximum density of rotifers in April reproduces a massive increase of diatoms and colonial green algae as the majority of species present in water are herbivorous filter feeders. Sládeček [45] in his research make a reference to a very eutrophic fishpond with abundance as high as 23,900 ind/L. High abundance values of rotifers in spring (over 30,000 ind/L) were also observed in naturally eutrophic two arms in the Morava River floodplain [46]. The spring phase of rotifer development was followed by a rapid drop in its density which is quite typical for the summer season [47]. From August on, no rotifer development was spotted and the quantity of these species dropped significantly most likely due to the existence of cyanobacteria. One of the most undesirable aspects of cyanobacteria is an eventual production of toxins [33]. As Dumont [48] states, the extra cellular substances of cyanobacteria are toxic for rotifers so they repress their development. At that time the species typical for self-purification reservoirs of sewage (Brachionus budapestinensis and Filinia longiseta) ruled in the rotifer community, so did the ones which are the indicators of deteriorating saprobic conditions in waters [45].

After a spring development of algae we suppose the increase of density of filter feeder planktonic crustaceans [49], e.g. large cladocerans grazers and herbivorous copepods (Eudiaptomus). Large grazers are able to control phytoplankton biomass even under hypereutrophic condition (up to $1600 \mu \mathrm{g} / \mathrm{L}$ ) [50]. But despite the reach food source in the water basin in Modra, there were neither herbivore copepods observed at all, nor large filter feeders from the genus Daphnia; moreover, we did not even record the species Bosmina longirostris. It can be explained by the lack of edible food here. The typical net zooplankton species for eutrophic water and fishponds are small cladocerans Bosmina longirostris and B. coregoni, and a high abundance of cyclopoid copepods Thermocyclops and Eudiaptomus [3,32,51]. Our findings documented the occurrence of only two small cladocerans Alona rectangula and Chydorus sphaericus, which were observed in plankton in a small abundance. Both species were spotted in plankton of extremely hypertrophic water bodies by Sládeček and Sládečková [52]. The poor abundance of planktonic crustaceans was most likely due to cyanobacteria which strongly proliferated as far back as the beginning of the vegetation season and were less edible for filter feeders than small algae. Particularly, the larger colonial and filamentous cyanobacteria cannot serve as food source for zooplankton because of its parameters [49] as well as its eventual toxicity [33]. Mayer et al. [32] also recorded a significant decrease in zooplankton biomass over the summer development of cyanobacteria which, as they claim, was determined by changes in food source and the increase of water temperature.

3) We assume that the direct consequence of the high production of phytoplankton was the excessive consumption of oxygen near the bottom of the basin which led to anoxia. Presumably, the adverse conditions (anoxia) at the bottom of the basin contributed to the occurrence of some benthic species, e.g. Spirostomum teres and Holophrya teres, in the plankton. Moreover, ciliate densities 
in the June plankton $(\approx 6000 \mathrm{ind} / \mathrm{mL})$ were several times higher than those in the benthos, which is a rare phenomenon in the protozoan communities. Also Finlay [53] noted that ciliates can migrate from the benthic zone into the water column depending on the oxygen content. Moreover, he argued that species bigger than $150 \mu \mathrm{m}$, such as Loxodes and Spirostomum, do not migrate. However, we observed high abundances of Spirostomum teres not only in the benthos but also in the plankton during May. This essentially supports Finlay's migratory theory also for this species.

\section{Conclusion}

The seasonal development of the phytoplankton, phytobenthos, zooplankton and microbenthos of a highly eutrophised intravilan water reservoir was investigated. The cyanobacterial bloom and high chlorophyll-a content, as a consequence of a high phosphorus concentration, influenced the seasonal dynamic of the plankton and microbenthos communities. The highest concentration of TRP was recorded from March to early April. Subsequently the boom of the planktonic communities occurred in that ciliates and rotifers reached the highest abundance and biomass, and the green colonial alga Golenkiniopsis longispina manifested a mass development. The cyanobacterial water bloom, composed mainly from the colonies of Microcystis ichtyoblabe, started in May without any significant influence on the planktonic communities of the reservoir. However, the colonies of chroococcal picoplanktic cyanobacterium, with cells 1 $2 \mu \mathrm{m}$ in diameter, dominated very strongly during the summer. Consequently the densities of ciliates and other zooplankton dropped significantly. Paced plankton sank to the bottom and started to decompose, which resulted in oxygen depletion. As a consequence of anoxia, the massive and multiple occurrences of benthic protozoa in the plankton were observed in June. The ciliate densities in the plankton were several times higher than those in the benthos. From August on, in the second half of the vegetation season, a considerable drop in abundance of planktonic invertebrates was observed, most likely due to the presence of cyanobacteria.

\section{Acknowledgements}

This study was supported by APVV, project No. 0566-07, VEGA projects No. 1/0600/11 and 2/0113/13. This publication is the result of the project implementation: Comenius University in Bratislava Science Park supported by the Research and Development Operational Programme funded by the ERDF Grant number: ITMS 26240220086 . The study was also supported by the project ITMS: 26240220049.

\section{REFERENCES}

[1] D. W. Schindler and J. R. Vallentyne, "The Algal Bowl: Overfertilization of the World's Freshwaters and Estuaries," University of Alberta Press, Edmonton, 2008.

[2] J. D. Allan, "Landscapes and Riverscapes: The Influence of Land Use on Stream Ecosystems," Annual Review of Ecology, Evolution, and Systematics, Vol. 35, 2004, pp. 257-284.

http://dx.doi.org/10.1146/annurev.ecolsys.35.120202.110 $\underline{122}$

[3] V. Kořínek, J. Fott, J. Fuksa, J. Lellák and M. Pražáková, "Carp Ponds of Central Europe," In: R. G. Michael, Ed., Managed Aquatic Ecosystems, Elsvier Sci. Pub. B.V., Amsterdam, 1987, pp. 26-61.

[4] M. Salvia-Castellvi, A. Dohet, P. Vander Borght and L. Hoffman, "Control of the Eutrophication of the Reservoir of Esch-sur-Sûre (Luxembourg): Evaluation of the Phosphorus Removal by Predams," Hydrobiologia, Vol. 459, No. 1-3, 2001, pp. 61-71. http://dx.doi.org/10.1023/A:1012548006413

[5] D. M. Anderson, P. M. Glibert and J. M. Burkholder, "Harmful Algal Blooms and Eutrophication: Nutrient Sources, Composition, and Consequences," Estuaries, Vol. 25, No. 4, 2002, pp. 704-726. http://dx.doi.org/10.1007/BF02804901

[6] G. A. Codd, "Cyanobacterial Toxins, the Perception of Water Quality and the Priorisation of Eutrophication Control," Ecological Engineering, Vol. 16, No. 1, 2000, pp. 51-60. http://dx.doi.org/10.1016/S0925-8574(00)00089-6

[7] Y. Yamamoto, H. Tsukada and Y. Matsuzawa, "Relationship between Environmental Factors and the Formation of Cyanobacterial Blooms in a Eutrophic Pond in Central Japan," Algological Studies, Vol. 134, No. 1, 2010, pp. 25-39.

http://dx.doi.org/10.1127/1864-1318/2010/0134-0025

[8] E. Lelková, M. Rulík, P. Hekera, P. Dobiáš, P. Dolejš, M. Borovičková and A. Poulíčková, "The Influence of the Coagulant PAX-18 on Planktothrix agardhii Bloom in a Shallow Eutrophic Fishpond," Fottea, Vol. 8, No. 2, 2008, pp. 147-154.

[9] S. R. Carpenter, "Complex Interactions in Lake Communities," Springer Verlag, 1988.

http://dx.doi.org/10.1007/978-1-4612-3838-6

[10] S. R. Carpenter, N. F. Caraco, D. L. Correll, R. W. Howarth, A. N. Sharpley and V. H. Smith, "Nonpoint Pollution of Surface Waters with Phosphorus and Nitrogen," Ecological Applications, Vol. 8, No. 3, 1998, pp. 559-568. http://dx.doi.org/10.1890/1051-0761(1998)008[0559:NP OSWW]2.0.CO;2

[11] A. Herzig, "The Zooplankton of the Open Lake," In: H. Löffler, Ed., Neusiedlersee. Limnology of a Shallow Lake in Central Europe, Dr. W. Junk Publishers, Hague, 1979, pp. 281-336. http://dx.doi.org/10.1007/978-94-009-9168-2 22

[12] J. Komárek and B. Fott, "Chlorophyceae (Grünalgen), Ordnung: Chlorococcales," Die Binnengewässer, Vol. 16, No. 7, 1983. 
[13] F. Hindák, "Colour Atlas of Cyanophytes," Veda, Bratislava, 2008.

[14] K. Krammer and H. Lange-Bertalot, "Bacillariophyceae, 1. Teil: Naviculaceae, "Süßwasserflora von Mitteleuropa, Vol. 2, No. 1, 1986.

[15] K. Krammer and H. Lange-Bertalot, "Bacillariophyceae, 2. Teil: Bacillariaceae, Epithemiaceae, Surirellaceae," Süßwasserflora von Mitteleuropa, Vol. 2, No. 2, 1988.

[16] K. Krammer and H. Lange-Bertalot, "Bacillariophyceae, 3. Teil: Centrales, Fragilariaceae, Eunotiaceae," Süßwasserflora von Mitteleuropa, Vol. 2/3, 1991a.

[17] K. Krammer and H. Lange-Bertalot,"Bacillariophyceae, 4. Teil: Achnanthaceae, Kritische Ergänzungen zu Navicula (Lineolatae) und Gomphonema," Süßwasserflora von Mitteleuropa, Vol. 12/4, 1991b.

[18] W. Foissner, H. Blatterer, H. Berger and F. Kohmann, "Taxonomische und Ökologische Revision der Ciliaten des Saprobiensystems Band I.," Informationsberichte des Bayer. Landesamtes für Wasserwirtschaft, Vol. 1, 1991.

[19] W. Foissner, H. Blatterer, H. Berger and F. Kohmann, "Taxonomische und Ökologische Revision der Ciliaten des Saprobiensystems Band II.," Informationsberichte des Bayer. Landesamtes für Wasserwirtschaft, Vol. 5, 1992.

[20] W. Foissner, H. Berger and F. Kohmann, "Taxonomische und Ökologische Revision der Ciliaten des Saprobiensystems Band III, " Informationsberichte des Bayer. Landesamtes für Wasserwirtschaft, Vol. 1, 1994.

[21] W. Foissner, H. Berger, H. Blatterer and F. Kohmann, "Taxonomische und ökologische Revision der Ciliaten des Saprobiensystems Band IV, Gymnostomatea, Loxodes, Suctoria," Informationsberichte des Bayer. Landesamtes für Wasserwirtschaft, 1995.

[22] W. Foissner, H. Berger and J. Schaumburg, "Identification and Ecology of Limnetic Plankton Ciliates," Informationsberichte des Bayer, Landesamtes für Wasserwirtschaft, München, Vol. 3/99, 1999.

[23] F. D. Morduchaj-Boltovskoj, "Materialy po Srednemu vesu Bespozvonochnykh Basseǐna Dona," Trudi Problemnih i Tematičeskih Sovešcanija, Zool. Inst. 2, Problemy Gidrobiologii Vnutrennych Vod, Vol. 2, 1954, pp. 223-214.

[24] S. N. Ulomskij, "Rol' Rakoobraznych v Obshchej Biomasse Planktona ozer (K Voprosu o Metodike Opredeleniya Vidovoj Biomassy Zooplanktona)," Trudi Problemnih i Tematičeskih Sovešcanija, Zool. Inst., 1, Problemy Gidrobiologii Vnutrennych Vod, Vol. 1, 1951.

[25] S. N. Ulomskij, "Syroĭ ves Massovykh Form Nizshikh Rakoobraznykh Kamskogo Vodokhranilischa i Nekotorykh ozer Urala i Zaural'ya," Trudi Uraljskogo otdeleniya Gosudarstvennogo Nauchno-Issledovateljskogo Institute Ozernogo i Rechnogo, Ribnogo Khozyaystva, Vol. 5, 1961, pp. 200-210.

[26] A. Nauwerck, "Die Beziehungen Zwischen Zooplankton und Phytoplankton im See Erken," Acta Universitatis Upsaliensis: Symbolae Botanicae Upsalienses, Vol. 17, No. 5, 1963, pp. 1-163.

[27] B. Düssart, "Limnologie. L'étude des eaux Continen- tales, " Guathier-Villars, Paris, 1966.

[28] F. Hindák and A. Hindáková,“ Cyanobacteria and Algae of a Small Eutrophic Water Reservoir at Modra (W Slovakia)," Bulletin Slovenskej Botanickej Spoočnosti, Vol. 32, No. 2, 2010, pp. 129-135.

[29] E. Tirjaková, "Ciliated Protozoa Communities (Protozoa: Ciliophora) in Hypertrophic Shallow Water Reservoir in Modra (W Slovakia)," Folia faunistica Slovaca, Vol. 15, No. 1, 2010, pp. 33-41.

[30] W. Lampert and U. Sommer, "Limnoökologie," Thieme Veralg, Stuttgart, New York, 1993.

[31] M. Fulín, I. Hudec, E. Sitášová, V. Slobodník and P. Sabo, "Environmentálno-Ekonomické Vyhodnotenie Funkcií a Hospodárenia v Rybníkoch na Slovensku," Nadácia IUCN, Svetová únia Ochrany Prírody, Slovensko, IUCN Gland, Švajčiarsko a Cambrige, Vel'ká Británia, 1994.

[32] J. Mayer, M.T. Dokulil, M. Salbrachter, M. Berger, T. Posch, G. Pfister, A. K. T. Kirschner, B. Velimirov, A. Steitz and T. Ulbricht, "Seasonal sUccession and Trophic Relations between Phytoplankton, Zooplankton, Ciliate and Bacteria in a Hypertophic Shallow Lake in Vienna, Austria," Hydrobiologia, Vol. 342-343, 1997, pp. 165174. http://dx.doi.org/10.1023/A:1017098131238

[33] B. Maršálek, V. Keršner and P. Marvan, "Vodní Květy Sinic," Nadatio flos-aquae, Brno, 1996.

[34] A. J. Wade, G. M. Hornberger, P. G. Whitehead, H. P. Jarvie and N. Flynn, "On modelling the Mechanisms That Control In-Stream Phosphorus, Macrophyte, and Epiphyte Dynamics: An Assessment of a New Model Using General Sensitivity Analysis," Water Resource Research, Vol. 37, No. 11, 2001, pp. 2777-2792. http://dx.doi.org/10.1029/2000WR000115

[35] J. Lucey, J. J. Bowman, K. J. Clabby, P. Cunningham, M. Lehane, M. MacCarthaigh, M. L. McGarrigle and P. F. Toner, "Water Quality in Ireland (1995-1997)," Environmental Protection Agency, Wexford, 1999.

[36] P. J. Dillon and F. H. Rigler, "A Test of the Simple Nutrient Budget Model Predicting the Phosphorus Concentration in Lake Water," Journal of the Fisheries Research Board of Canada, Vol. 31, No. 11, 1974, pp. 1771-1778. http://dx.doi.org/10.1139/f74-225

[37] B. Maršálek, "Hledání Achilovy Paty u Cyanobaktérií," In: M. Rulík, Ed., Limnologie na Přelomu Tisíciletí, Conference proceedings, Kouty nad Desnou, 2000, pp. 88-93.

[38] K. T. Kiss and S. I. Genkal, "Winter Blooms of Centric Diatoms in the River Danube and in Its Side-Arms near Budapest (Hungary)," Hydrobiologia, Vol. 269-270, No. 1, 1993, pp. 317-325 http://dx.doi.org/10.1007/BF00028030

[39] F. Hindák and A. Hindáková, "Checklist of Cyanobacteria and Algae of Slovakia," In: K. Marhold and F. Hindák, Eds., Checklist of Non-Vascular and Vascular Plants of Slovakia, Veda, Bratislava, 1998, pp. 12-100.

[40] F. Hindák and A. Hindáková, "Cyanophytes and Algae of Gravel Pit Lakes in Bratislava, Slovakia: A Survey," Hydrobiologia, Vol. 506-509, No. 1-3, 2003, pp. 155-162. http://dx.doi.org/10.1023/B:HYDR.0000008631.82041.c7

[41] R. J. P. Dias and M. D'Agosto, “Feeding Behavior of 
Frontonia leucas (Ehrenberg) (Protozoa, Ciliophora, Hymenostomatida) under Different Environmental Conditions in a Lotic System," Revista Brasileira de Zoologia, Vol. 23, No. 3, 2006, pp. 758-763.

http://dx.doi.org/10.1590/S0101-81752006000300021

[42] K. Šimek, J. Bobková, M. Macek and J. Nedoma, "Ciliate Grazing on Picoplankton in a Eutrophic Reservoir during the Summer Phytoplankton Maximum: A Study at the Species and Community Level," Limnology and Oceanography, Vol. 40, No. 6, 1995, pp. 1077-1090. http://dx.doi.org/10.4319/10.1995.40.6.1077

[43] B. Vörösváry, "A Kalános Patak Csillós Véglényei," Annales Biologicae Universitatis Szegediensis Szeged, Vol. 1, 1950, pp. 343-387.

[44] J. A. Laybourn-Parry, "Protozoan Plankton Ecology," Chapman \& Hall, London, 1992.

[45] V. Sládeček, "Rotifers as Indicators of Water Duality," Hydrobiologia, Vol. 100, No. 1, 1983, pp. 169-201. http://dx.doi.org/10.1007/BF00027429

[46] M. Illyová, "Zooplankton of Two Arms in the Morava River Floodplain in Slovakia," Biologia, Vol. 61, No. 5, 2006, pp. 531-539. http://dx.doi.org/10.2478/s11756-006-0087-8

[47] M. Devetter, "Influence of Environmental Factors on the Rotifer Assemblage in an Artificial Lake," Hydrobiologia, Vol. 387/388, 1998, pp. 171-178.
[48] H. J. Dumont, "Biotic Factors in the Population Dynamics of Rotifers," Archiv für Hydrobiologie, Beiheft Ergebnisse der Limnologie, Vol. 8, 1977, pp. 98-122.

[49] U. Sommer, M. Gliwitcz, W. Lampert and A. Duncan, "The PEG-Model of Seasonal Succession of Planktonic Events in Fresh Waters," Archiv fuer Hydrobiologie, Vol. 106, No. 4, 1986, pp. 433-471.

[50] K. Vakkilainen, T. Kairesalo, J. Hietala, D. M. Balayla, E. Bécares, W. J. Van de Bund, E. Van Donk, M. FernándezAláez, M. Gyllström, L-A. Hansson, M. R. Miracle, B. Moss, S. Romo, J. Rueda and D. Stephen, "Response of Zooplankton to Nutrient Enrichment and fish in Shallow Lakes: A Pan-European Mesocosm Experiment," Freshwater Biology, Vol. 49, No. 12, 2004, pp. 1619-1632. http://dx.doi.org/10.1111/j.1365-2427.2004.01300.x

[51] Z. M. Gliwicz, "Studies on the Feeding of Pelagic Zooplankton in Lake with Varying Trophy," Ekologia Polska, Vol. 17A, 1969, pp. 663-708.

[52] V. Sládeček and A. Sládečková, "Biologie Stabilizačních nádrží," X. Limnologická Konference (Conference Proceedings), Stará Turá, 1994, pp. 178-190.

[53] B. J. Finlay, "Oxygen Availability and Seasonal Migrations of Ciliated Protozoa in a Freshwater Lake," Journal of General Microbiology, Vol. 123, No. 1, 1981, pp. 173178. 